\title{
A Comparative Analysis of Board Disclosures of Selected Pharmaceuticals Companies of Bangladesh and the UK
}

\author{
Rehenuma Rahman ${ }^{1, *} \&$ Md. Anwarul Kabir ${ }^{2}$ \\ ${ }^{1}$ Department of Accounting, Adam Smith Business School, University of Glasgow, Glasgow \\ G12 8QQ, UK \\ ${ }^{2}$ State University of Bangladesh, 77, Satmasjid Road Dhanmondi, Dhaka 1205, Bangladesh \\ *Corresponding author: Department of Accounting, Adam Smith Business School, University \\ of Glasgow, Glasgow G12 8QQ, UK. Tel.: 44-745-919-2325. E-mail: \\ rehenuma.rahman@yahoo.com
}

Received: February 18, 2019 Accepted: May 27, 2019 Published: July 10, 2019

doi: 10.5296/jcgr.v3i1.14765 URL: https://doi.org/10.5296/jcgr.v3i1.14765

\begin{abstract}
This research aims to compare the board disclosures in the annual reports of selected pharmaceutical companies in the UK and Bangladesh. The sample consists of 10 purposively selected pharmaceutical companies from both countries. A secondary qualitative research has been held on 10 board issues: board size, board composition, director's qualification, board training, board independence, board meetings, independent directors, board committees, director's remuneration and director's report. The findings indicate that the Bangladesh Security Exchange Commission's (BSEC) Corporate Governance Notification, 2012 has limited scope compared with the UK Corporate Governance Code, 2014. Selected UK companies are following the UK Corporate Governance Code, 2014 stringently and disclosing all necessary board disclosures in detail manner as per the requirement of the code, whereas none of the sampled Bangladeshi companies are publishing 100\% mandatory board disclosures in detailed manner however they still attach a corporate governance compliance certificate in their annual report. The existing corporate governance notification should be improved which will accelerate the extent of mandatory disclosures. The multitude of voluntary disclosure is quite low in Bangladeshi companies compared with UK companies.
\end{abstract}

Keywords: Board of directors, board disclosures, mandatory disclosures, voluntary disclosures, UK, Bangladesh 


\section{Introduction}

\subsection{Problem Statement}

In 1997, during the Asian financial crisis, there was a specific requirement for corporate governance reform, with a focus on making appropriate disclosures (Hong Kong Society of Accountants (HKSA), 2001). Though poor disclosure, did not contribute to recession directly it intensified the consequences (HKSA, 2001). Disclosures are authorized by law as a governance mechanism to assuage the agency problem caused by the split of ownership and management of companies (Jensen \& Meckling, 1976, Mahoney, 1995). Disclosures can be either mandatory or voluntary which are assembled under the guidance of an authoritative body (board of directors, CEO/Chairman, top-level management etc.) to correspond to various stakeholders. Mandatory disclosures are the information that the entities are required to publish by law (Dey, 2015). Voluntary Disclosure indicates disclosing information beyond the mandatory components in the annual reports (Kumar, Wilder, and Stocks, 2008) which may lessen information asymmetry by making information available to the public (Evan \& Sridhar, 1996). Companies may engage in selective disclosures by only disclosing information that creates a positive company image to stakeholders (Sharma et al., 2012). The current research attempts to comparatively analyze the board of directors' related disclosure practices of selected pharmaceutical companies in the UK and Bangladesh. The pharmaceutical industry has been chosen as it is a highly regulated, technology intensive industry and has a significant contribution to the Bangladesh and UK economy. Moreover, though Bangladesh and the UK is the opposite end of the spectrum, these two countries have been selected for a few reasons. Bangladeshi corporate laws have basically adapted from British Laws in their content and interpretation while the UK is a strict follower of corporate governance regulations in disclosing mandatory information, most of the Bangladeshi companies are reluctant to do so. Thus, this comparative analysis will explore the potential variation of Board disclosure practices in developing and developed economies.

\subsection{Theoretical Considerations}

According to Nicholson and Kiel (2007) "Agency theory, stewardship and resource dependence theories undoubtedly assisted to understand the role that directors may play in contributing to the performance of the organizations they govern. Agency theory (Jensen and Meckling, 1976) examines how board composition and board leadership/CEO/chairman duality affects corporate performance (Nicholson \& Kiel, 2007). A higher proportion of independent directors will monitor managers so that managers will have less opportunity to pursue self-interest at the expense of the owners and shareholders will also enjoy greater returns" (Nicholson \& Kiel, 2007). Agency theory predicts CEO and chairman roles are separate incumbents. A countervailing view to agency theory, stewardship theory suggests that a higher proportion of executive directors in the board add to the superior knowledge and expertise than that of outside directors which results in higher corporate performance (Donaldson, 1990). In contrast to CEO-chairman duality, stewardship theory suggests when the chairperson and the CEO is the same person; the command becomes unified, removing role ambiguities and conflicts which lead to higher corporate financial performance (Donaldson, 
1990). The third major theory of corporate governance, resource dependence theory says that the board connects firm and the essential resources to maximize performance (Pfeffer \& Salancik, 1978). While the board's ability to access key resources is seen as important, the exact nature of the resources is variable and the value of a particular resource depends on the urgency of the need (Nicholson \& Kiel, 2007).

\section{Corporate Governance Disclosures: School of Thought}

The disclosure acts as a powerful corporate governance mechanism. According to HKSA (2001), "Corporate governance disclosure regime screens corporate culture and investors' capacity in practicing voting rights. Investors, shareholders and institutional stakeholders approach to firm and comparable information to assess management's efficiency and decide the valuation, ownership and voting rights. Insufficient information hinders the capital markets to do its duties productively, escalates capital expenditure and result in inefficient distribution of assets. Example of countries with excellent corporate governance regime shows that disclosure helps to protect investors, attract capital and smoothes capital markets' activities. Disclosures also improve shareholder's knowledge of the company's financial and corporate stability, company strategies regarding the environment, ethics and responsibilities toward communities" (HKSA, 2001). Corporate governance regulations have been varied from country to countries.

U.S. public companies are mainly regulated by state corporate laws, federal securities laws, the company's certificate of incorporation and bylaws, and the enlisting regulations of the stock exchanges (International Comparative Legal guides (ICLG, 2017). The Delaware General Corporation Law has been the most significant jurisdiction in United States corporate law since the beginning of the 20th century. More than $66 \%$ of publicly-listed companies in the USA are incorporated in the state (State of Delaware official website, 2017). Besides this, other Federal securities laws and reports includes Securities and Exchange Act, 1934, National Association of Corporate Directors (NACD) report 1996, Business Roundtable (BRT) reports 1997 Gramm-Leach-Billy Act, 1999, Sarbanes-Oxley Act (SOX) in July 2002, Dodd-Frank Act, 2010, JOBS Act, 2012 etc. but the most remarkable one is SOX, 2002. After the Enron debacle in 2001, there were other corporate scandals in large US companies like World com, Qwest Global Crossing, Anderson which ultimately triggered the enforcement of the SOX, 2002. SOX brought an underlying transition in the board structure, auditing, financial reporting and corporate disclosure (Chandra Report, 2002) through empowerment of the SEC; reformation and re-empowerment of the board members; ratification of corporate codes of ethics etc. (Soni, 2015).

The Corporate Governance Code for Germany was produced by 'The Berlin Initiative Group' and titled as 'German Code of Corporate Governance' in June 2000 which was amended in 2010. It provides the necessary guidelines for managing and supervising (governance) of German listed companies and brings transparency in the German Corporate Governance system. German listed companies use a dual board system where the Management Board manages the enterprise and Supervisory Board appoints, supervises and advises the 
Management Board and is involved in decisions making. The board disclosures involved in German Code are Composition and Compensation (4.2, 5.4), Conflicts of Interest (4.3, 5.5), Tasks and Responsibilities of the Supervisory Board (5.1), Tasks and Authorities of the Chairman of the Supervisory Board (5.2), Formation of Committees (5.3) Reporting and Audit of the Annual Financial Statements (7).

In Japan, 'Corporate Governance Principles' was prepared by the Corporate Governance Committee of the Corporate Governance Forum of Japan in 1998 which was amended in 2015 as Corporate Governance Code. The code designates principles for Japanese listed companies for sound corporate governance. Two of the major principles related to corporate and board disclosures are- Ensuring Appropriate Information Disclosure and Transparency and The responsibilities of the Board. Companies should report information to conform the relevant laws to ensure transparency in board decision and develop efficient corporate governance. The board should assure that the board disclosures are accurate and useful for the stakeholders.

In India, the Confederation of Indian Industry (CII) was the first to set desirable standards for Indian corporations. After that some other corporate governance law have been enacted in India, including Kumar Mangalam Birla Report, 1999, Chandra Report, 2002, Narayana Murthy Committee Report, 2003, Principles of Good Corporate Governance and Best Practice Recommendations, 2003, SEBI Clause 49 (2004), CII's Corporate Governance Recommendations for Voluntary Adoption, 2009, MCA's Corporate Governance Voluntary Guidelines 2009, Guiding Principles of Corporate Governance, 2012 etc. The Principles of Corporate Governance, 2012 outlined a few steps of board related disclosures like Board composition and diversity, Appointing independent directors, Board Induction, Lead Independent Director, Information Acquisition, Recording of Minutes, Board Training, Board Evaluation, Maintaining Board Confidentiality, Succession Planning of CEOs and senior management etc. The Indian Companies Act of 2013 introduced some new provisions regarding board composition, female directors and independent directors, which benefit directors and stakeholders of companies to upgrade board governance practices in India. It also said every company should publicize information on financial performance, ownership and governance. According to this law, SEBI conducted necessary amendments for listed Indian companies.

Since 1992, the UK has been playing a prominent role in ensuing global corporate governance reforms. Listed UK companies follow UK Corporate Governance Code 2014 which embodied the previous reports e.g. Cadbury Report, 1992; Greenbury Report, 1995; Hampel Report, 1998; Turnbull Report, 1999; Higgs Report, 2003; Smith Report, 2003; FRC, 2010-2012. The five main principles of Corporate Governance Code 2014 are; leadership, effectiveness, accountability, remuneration and relations with shareholders. The UK code is a guide for ensuring board effectiveness.

After conducting research on numerous UK listed companies from diverse sectors (i.e. Alternative Investment Market (AIM), financial, non-financial, higher education institutions (HEIs)) academics postulated that board size (Mallin \& Ow-Yong, 2009, Al-Najjar \& Abed, 2014), audit committee independence (Al-Najjar \& Abed, 2014), the percentage of 
independent outside directors (Elmagrhi, Ntim, \& Wang, 2016), gender and ethnic diversity of the directors (Ntim, 2015; Elmagrhi, Ntim, \& Wang, 2016), quality of audit committee, presence of governance committee (Ntim, Soobaroyen, \& Broad, 2015) are positively linked with voluntary disclosures (Mallin \& Ow-Yong, 2009, Elmagrhi, Ntim, \& Wang, 2016, Ntim et al, 2017) and future-related information in the annual reports (Al-Najjar \& Abed, 2014). By contrast, other scholars opined board independence (Abdelsalam \& Street, 2007, Al-Najjar \& Abed, 2014), CEO-Chairman duality (Abdelsalam \& Street, 2007), board size (Ntim et al., 2017) are negatively connected to voluntary disclosure in the annual report (Ntim et al., 2017).

While conducting research on UK listed firms; academics proved corporate governance characteristics (board size, portion of non-executive directors, CEO duality etc.) can influence other disclosures too. Companies with the existence of a board sub-committee, larger audit committees positively influence disclosures related to intellectual capital (Li, Pike, \& Haniffa, 2008), greenhouse gas (Chithambo \& Tauringana, 2017) whereas CEO duality do not influence these disclosures. Though independent directors tend to provide greater intellectual capital disclosure in their annual reports (Li, Pike \& Haniffa, 2008) they do not influence greenhouse gas disclosure (Chithambo \& Tauringana, 2017).

In Bangladesh, the predecessor of corporate governance guideline is the Companies Act 1994, BEI Report 2003, Corporate Governance Notification, 2006, Bangladesh Bank (BB) corporate governance circular 2010. Bangladesh Security \& Exchange Commission (BSEC) Notification, 2012 replaced Corporate Governance Notification, 2006. BSEC Notification, 2012 monitors and regulates corporate governance of listed Bangladeshi companies. It contains seven sections dealing with the board of directors; CFO, Head of Internal Audit, Company Secretary; External Auditors; Subsidiaries; Duties of CEO and CFO; Reporting and compliance of corporate governance. To assure board effectiveness, some reforms are conducted in cases of nomination and qualification criteria of independent directors, code of conduct of board members, director's report etc in the BSEC Notification, 2012 (Biswas, 2012).

Existing literature showed that the corporate governance disclosure practices are not very satisfactory level in Bangladesh. Nicholls and Ahmed (1995), Aktharuddin (2005), Haque (2007) found the quantity of mandatory disclosure is very low in Bangladesh meanwhile Rahman 1999 found the opposite. Though the overall disclosure level is 67\% in Bangladesh (Hasan \& Hossain, 2012); the degree of voluntary disclosure is 12\% (Hossain et al., 2005), $47.74 \%$ (Rouf, 2011) and mandatory disclosure is 44\% (Aktharuddin, 2005). Therefore Rashid et al, 2010 concluded weak disclosure practice is one of the characteristics of corporate governance of Bangladeshi companies. Meanwhile neighbouring country India, has achieved the highest standard in mandatory disclosure and has progressed in voluntary disclosure too (Hossain, 2008). Bhuiyan, Ullah, and Biswas (2007) found board size do not significantly influence corporate governance disclosure index in Bangladesh which was refuted by Islam, Al-Hossienie, and Al-Baki (2010). Conversely, Rouf (2011) found board size, board leadership structure and audit committee has a positive correlation with voluntary disclosures.

The amplitude of corporate disclosure fluctuates country to country. In Bangladesh the companies disclosed $44 \%$ of items of mandatory information (Aktharuddin, 2005) whereas the 
percentage is $88 \%$ in India (Hossain, 2008), 90\% in Egypt (Hassan et al., 2009), 66\% in China (Cheung, Jiang, \& Tan, 2010), 91\% in The UK (Arcot et al., 2010), 72\% in Kuwait (Alanezi \& Albuloushi, 2011), 91\% in Nepal (Sharma, 2014). Moreover, previous academic researchers showed low levels of voluntary disclosure in different countries i.e. $12 \%$ in Bangladesh (Hossain, Salat, \& Al-Amin, 2005), 25\% in India (Hossain, 2008), 37\% in Qatar (Hossain \& Hammami, 2009), 47.74\% in Bangladesh (Rouf, 2011), 37\% in Greece (Leventis \& Weetman, 2004), 46\% in Kuwait (Al-Shammari, 2008), 31\% in Malaysia (Ghazali \& Weetman, 2006), $48 \%$ in Nepal (Sharma, 2014).

The level of disclosure is a decision taken imperatively by the board of directors, which also reduces agency problems (Akhtaruddin, Hossain, Hossain, \& Yao, 2009). Board of directors' furnishes stakeholders with adequate financial and operating disclosures of the entity whose governance has been assigned to the board (Dey, 2015). Researchers are also broken down into different branches in discussing board disclosures practices. The first stream of researchers concentrated on board size. Arcay and Vázquez, 2005 found smaller board provide more voluntary information where some other academics opined larger board provides more voluntary information as the board size is positively linked to the voluntary disclosures (Akhtaruddin, Hossain, Hossain, \& Yao, 2009, Rouf, 2011, Al-Janadi, Rahman, \& Omar, 2013). Another group posited that board size negatively effects voluntary disclosure (Bhuiyan, Ullah and Biswas 2007, Alves, Rodrigues, \& Canadas, 2012) while Alfraih, 2016 delineated that board size has a positive association with the level of mandatory disclosure.

Each board is constituted by the executive (inside) and non executive (outside) directors. Inside directors can be executive officers of a firm, management or the family members, mostly company employees while outside director (independent directors) is not a company employee and selected from outside (i.e. stakeholder representatives on boards, bankers, venture capitalists, politically-connected directors) (Adams, Hermalin, \& Weisbach, 2008; Akhtaruddin, Hossain, Hossain, \& Yao, 2009). The knowledge of executive directors balances any lacking of non-executive directors and makes the board efficient (De Andres \& Vallelado, 2008). Board composition is significant predictors of mandatory and voluntary disclosures (Hossain 2008). Voluntary disclosures can be either negative (Barako, Hancock, \& Izan, 2006) or positively (Sartawi Hindawi, Bsoul, \& Ali, 2014) affected by board composition. Voluntary disclosure has positive relations with the presence of foreign directors on the board (Sartawi, Hindawi, Bsoul, \& Ali, 2014). Moreover Voluntary disclosure is negatively connected with family directors (Ho \& Wong, 2001; Chau \& Gray, 2002) because family owned firms enjoy less incentive to serve more information to outside stakeholders (Akhtaruddin, Hossain, Hossain, \& Yao, 2009). The presence of family members on the board shows different result in two Middle-Eastern countries (Kuwait and Saudi Arabia) in similar institutional setting. Al-Janadi, Rahman, and Omar (2013) proved the distribution of family members on the Saudi board has a positive impact on the voluntary disclosure while Alfraih (2016) found family directors for Kuwait show negative influence on the mandatory disclosure. Family firms also experience weaker relationship between the apportionment of independent directors and financial disclosures (Chen \& Jaggi, 2000). On the other hand, in case of mandatory disclosure Dey (2015) evidenced that board members 
and shareholders emphasize on the mandatory disclosure of board composition. Haque, Jahan, and Khan (2007) argued that weak disclosure practices are the consequences of micro or macro level political behavior in Bangladesh. They revealed that most of the companies in Bangladesh do not come to the capital market to meet their financing needs partly because of increased disclosure requirements.

The board that is composed of higher number of independent directors enhances board independence (Hermalin \& Weisbach, 1998; Eng \& Mak, 2003; Laux, 2008). Academics proved board with more independent non-executive directors have a negative relation to voluntary disclosures (Ho \& Wong, 2001; Gul \& Leung, 2004; Barako, Hancock, \& Izan 2006; Rouf, 2011; Alves, Rodrigues, \& Canadas, 2012; Mollah \& Zaman, 2015). Another stream of research presented conflicting evidence that more independent directors enhance the magnitude of voluntary disclosure (Gul \& Leung, 2004; Donnelly \& Mulcahy, 2008; Arcay \& Vázquez, 2005; Akhtaruddin, Hossain, Hossain, \& Yao, 2009; Al-Janadi, Rahman, \& Omar, 2013). Furthermore, Dey (2015) in his study showed that though board members considered the appointment of independent directors is an important mandatory disclosure; shareholders disagreed with this notion.

CEO duality (CEOs who jointly serve as board chairs) contributes in lower levels of voluntary disclosures (Forker, 1992) since the board where CEO also serves as board chairman is less likely to monitor management and ensure transparency (Gul \& Leung, 2004, Rouf, 2011). Hence the CEO exercises more power over corporate decision-making (Adams, Almeida, \& Ferreira, 2005). However, Gul and Leung, 2004 concluded board with more independent directors experience a weak connection between CEO duality and voluntary disclosure. Another school of thought opines dual leadership (the chair of the board and CEO are different persons) is negatively associated with voluntary disclosure (Adams, Almeida, \& Ferreira, 2005; Arcay \& Vázquez, 2005; Barako, Hancock, \& Izan, 2006; Al-Janadi, Rahman, \& Omar, 2013). Contrarily Donnelly and Mulcahy (2008) proved that the bifurcation of "CEO", "Chairman" roles enhances voluntary disclosure. In case of mandatory disclosure, though CEO duality possesses negative linkage to mandatory disclosure (Alfraih, 2016), Dey (2015) found a board of directors prefer higher scores for mandatory disclosure on CEO-Chairman duality.

Board Committees contribute in lower levels of voluntary disclosures. Hossain, Salat, and Al-Amin (2005) found that $12 \%$ of companies disclosed voluntary information on Board Committees. Bhuiyan, Ullah and Biswas 2007 showed 23\% of the selected companies have audit committee, remuneration committee, and other committees, $33 \%$ of the companies have published information on the distribution of the committee members and $28 \%$ of the companies have discussed the role and functions of the committees in the annual report. Finally, they consummated that board committees are linked to lower corporate governance disclosure score.

Contrary to developed countries, in developing countries, the audit committee is treated as the most crucial board committee than that of nomination and remuneration committees. Sharma, 2014 found a higher proportion of Nepalese companies (98\%) reported about the 
mandatory disclosure requirement of an audit committee; other board committeesnomination committee (7\%) and remuneration committees (3\%) were not popular amongst Nepalese companies. Dey, 2015 showed Bangladeshi board members and depositors emphasizes on the mandatory disclosure of the role and responsibilities of the audit committee. That's why Bangladeshi banking companies are reporting 100\% mandatory information about the audit reports. Researchers found that audit committee positively influences voluntary disclosure (Ho and Wong, 2001, Barako, Hancock, \& Izan 2006 and Rouf, 2011). Conversely, Al-Janadi, Rahman \& Omar, 2013 found a negative association between audit committee independence and voluntary disclosure. One of the possible reasons is that there are no obligations in Saudi companies that determine the qualification and the role of audit committee members in the Saudi board (Al-Janadi, Rahman, \& Omar, 2013).

\section{Rationale of the Study}

Bangladesh and the UK are characterized as being at opposite ends of a spectrum. The UK is the 5th largest economy and Bangladesh is in 45th position (IMF, 2017). The UK has been the leader in corporate governance reform (Crombie, 2013), ranked 1st in the GMI Corporate Governance rating and UK firms are considered as having the best practices in Europe (Ferrarini et al., 2010) while Bangladeshi companies are exemplifying weak governance practice (Uddin \& Choudhury, 2008, Rashid et al., 2010).

The selection of the board governance practices in the UK and Bangladeshi was motivated by several factors. First of all, both of the countries follow common law jurisdiction and Anglo-American Model of corporate governance. Bangladeshi corporate laws have historically drawn inspiration from British Laws in their content and interpretation. Secondly, both of the countries follow "Majoritarian Voting model" (Pagano \& Volpin, 2005) in the governance systems. Finally, legislation like UK Company Act, 2006, UK Corporate Governance Code, 2014 has extra-territorial application. For example- GlaxoSmithKline is a British non-financial company and second biggest pharmaceutical companies in the world in 2017 (Dezzani, 2017) are operating in Bangladesh market since 1974. Hence, GSK establishes its operation in Bangladesh, if there are any changes in UK Corporate Governance Code, 2014, GSK must be sensitive to the global consequences of their conduct. Eventually, the Bangladeshi market also needs to adopt a vigilant approach while engaging in commercial transactions with GSK as it has a large market share in Bangladesh market (Grant Thornton, 2010). Likewise, UK companies also need to consider the corporate governance norms in different jurisdictions as the failure to comply these can have enormous cost, time and reputational consequences (Grant Thornton, 2010). By conducting a comparative analysis, this paper contributes to the debate on whether effective board disclosures associate with country-level characteristics and/or firm-specific factors and explores the potential variation of Board disclosure practices in developing and developed economies.

Single-sector study prevents research outcomes from being contaminated by cross-sectoral factors (Dedman, Lin, Prakash, \& Chang, 2008). Therefore, the pharmaceutical industry has 
been chosen in this research due to its highly regulated, technology intensive nature and significant contribution to the Bangladesh and UK economy. With more than 450 pharmaceutical companies, the UK ranks with the USA and Japan- in the leading position in biotechnology and pharmaceutical research (UK trade and investment fact sheet, 2006). Besides developing new medicines for many diseases, the UK pharmaceutical industry serves the British economy through generating income, employment, expertise and major investments (abpi.org.uk, 2017). In Bangladesh, Pharmaceutical industry is one of the fastest growing industries and has experienced a 5.22\% growth rate in 2015-16 (BBS, 2016). It has attracted both institutional and individual investors. In 2016- 2017, Bangladesh exported pharmaceutical products to 45 countries, which was worth USD 13.63 million (EPB, 2016).

In the Anglo-American model of corporate governance, the annual report contains the background information of the directors, executive and directors' compensation, corporate financial data, capital structure, patterns of shareholding and names of auditors among other information (emergingmarketsesg.net, 2005). On most systems, companies report board evaluation and executive's performance in the annual reports (Kabir, 2008). Research in corporate governance disclosure has generally concentrated on the extent of corporate governance disclosures in the annual reports of the companies (Bhuiyan, Ullah, \& Biswas, 2007). Studying annual reports of different companies will help to understand the company-wide and country-wide board disclosures practices. Therefore, this study obtained annual reports of the selected pharmaceutical companies to explore the similarities and dissimilarities between the UK and Bangladesh concerning the extent of mandatory and voluntary board of directors' disclosures.

\section{Research Objectives}

Based on a literature review and the research gap found the following research objectives were developed

- To compare BSEC Notification, 2012 and UK Corporate Governance Code, 2014 regarding mandatory and voluntary board of directors disclosures in the annual reports of the selected pharmaceutical companies

- To assess the extent of mandatory and voluntary board of directors disclosures in the annual reports of the selected pharmaceutical companies of Bangladesh in compliance with BSEC Notification, 2012.

- To assess the extent of mandatory and voluntary board of directors disclosures in the annual reports of the selected pharmaceutical companies in the UK in compliance with UK Corporate Governance Code, 2014. 


\section{Methods}

To ensure sound corporate governance, Bangladeshi listed companies follow the Bangladesh Securities and Exchange Commission (BSEC) Corporate Governance Notification, 2012, UK companies follow the UK Corporate Governance Code, 2014. These are the basis of this research. The companies were selected using purposive sampling according to their stock exchange enlistment and the availability of the annual reports. In Bangladesh, there are 12 pharmaceutical companies listed in the Dhaka and Chittagong stock exchange:- Ambee Pharma does not publish an annual report and the six other companies (Beximco, Renata, Central, Pharma aid, Beacon, Ibn Sina) disclosed only a few boards ( $1 / 2$ sentences) of directors' related information in their annual report. Therefore, the five remaining companies (Square, GlaxoSmithKline, ACI, ACME and Orion Pharma) were selected for this research due to the sufficient board related disclosures in their annual report. In the UK, three FTSE 100 (GlaxoSmithKline, AstraZeneca, Shire, Hikma) and a FTSE 250 (BTG) pharmaceutical companies listed on the London stock exchange were selected for their reputation and market capitalization value. This qualitative research was conducted on mandatory and voluntary board disclosures published in the annual reports for 2015-2016 of the selected pharmaceutical companies.

Content analysis and thematic analysis have been used for analyzing data. The researcher has studied the annual reports of the selected Bangladeshi and UK companies to understand whether the UK and Bangladeshi companies are following UK Corporate Governance code, 2014 and BSEC notification, 2012 respectively to disclose mandatory board related disclosures in their annual report and the extent of voluntary board disclosures in their annual report. Ten of the board related issues (variables) have been considered in this research. On the basis of this thematic analysis the researcher reached to the conclusion

\section{Findings}

\subsection{Board Disclosures Issues}

\subsubsection{Board Size}

The average board size of the Bangladeshi pharmaceutical companies is 8 whereas in the UK it is 11. In the UK, the FTSE 100 (GlaxoSmithKline, AstraZeneca, Hikma, Shire) pharmaceutical companies have larger boards (more than 10 members) than that of the FTSE 250 (BTG) companies (8 members). In Bangladesh, only Orion disclosed the board size in the directors' report, which includes a number of boards of directors, re-elections and re-appointments. Other sampled Bangladeshi companies combined board size and board composition disclosures in a single paragraph, as did UK companies Hikma and BTG. Besides a number of boards of directors, UK companies AstraZeneca, GlaxoSmithKline, Shire didn't disclose anything regarding board size. 
Table 1. Profile of the Sampled Pharmaceutical Companies (Source: company website)

\begin{tabular}{|c|c|c|c|}
\hline Companies & Establishment & Turnover & Key product line \\
\hline Square & 1985 & BDT89,41,418,507 & $\begin{array}{l}\text { Therapeutic, Herbal \& Nutraceuticals, AgroVet \& } \\
\text { Pesticide }\end{array}$ \\
\hline GlaxoSmithKline & 1974 & BDT26,34,531,000 & Therapeutic, Consumer healthcare \\
\hline $\mathrm{ACI}$ & 1992 & BDT67,26,957,274 & $\begin{array}{l}\text { Tablets, capsules, injections, bottled products, creams, } \\
\text { inhaler }\end{array}$ \\
\hline ACME & 1954 & BDT12,644,913,144 & $\begin{array}{l}\text { Human (Steroid \& Hormone, Oncology, Ayurvedic, } \\
\text { Herbal \& Nutraceuticals), Veteriney }\end{array}$ \\
\hline Orion & 1965 & BDT14,799,743,435 & $\begin{array}{l}\text { Tablets, capsules, injections, syraps \& suspension, } \\
\text { creams }\end{array}$ \\
\hline AstraZeneca & 1999 & $\$ \mathrm{~m} 23,002$ & $\begin{array}{l}\text { Oncology, Cardiovascular \& Metabolic Disease, } \\
\text { Respiratory, Other }\end{array}$ \\
\hline BTG & 1991 & £m 447.5 & $\begin{array}{l}\text { Interventional Medicine (Oncology, Vascular, } \\
\text { Pulmonology), Specialty Pharmaceuticals }\end{array}$ \\
\hline GlaxoSmithKline & 2000 & $£ \mathrm{~m} 27,889$ & $\begin{array}{l}\text { Respiratory HIV, Specialty, Classic and Established } \\
\text { products, Vaccines, Consumer healthcare, }\end{array}$ \\
\hline Hikma & 1978 & $\$ \mathrm{~m} 1,950$ & Injectibles, Branded, Generics, \\
\hline Shire & 1986 & $\$ \mathrm{~m} 6,416.7$ & $\begin{array}{l}\text { GI \& Internal Medicine, Neuroscience, Ophthalmic, } \\
\text { Rare diseases }\end{array}$ \\
\hline
\end{tabular}

\subsubsection{Board Composition}

GlaxoSmithKline disclosed board composition in the director's report. Other selected Bangladeshi companies (i.e. ACI, ACME, Square, Orion) disclosed board composition in a separate paragraph, which includes information regarding the number of executive and independent directors (ACI, ACME) and re-election and re-appointment of the directors (Square).

UK companies either disclosed board composition separately (BTG, Hikma, Shire) or disclosed board composition disclosures in a "Board effectiveness" section (AstraZeneca) or Directors profile (GlaxoSmithKline). Key issues that the selected UK companies have published in the "Board composition" sections are skills and experience of the board members, changes in the board composition (AstraZeneca, GlaxoSmithKline); gender-national-cultural diversity (AstraZeneca, BTG, GlaxoSmithKline); number of executive/non-executive directors (BTG, Hikma, GlaxoSmithKline, Shire); director's profile, appointment and election of directors (BTG), tenure of independent directors (GlaxoSmithKline) and division of responsibilities (Shire).

Except for GlaxoSmithKline, 40-50\% of the directors of the Bangladeshi companies had been selected from the family, which supports the previous findings of Rashid, et al, 2010 and 
Uddin and Choudhury, 2008 that family dominance (family that owns the pharmaceutical company) is widely prevalent in the Bangladeshi boards. However, none of the selected UK companies have family members on the board except Hikma where important positions like Chairman/CEO and Executive Vice Chairman are family members. Chairman and CEO position is separate in all of the UK and Bangladeshi pharmaceutical companies, except Hikma.

\subsubsection{Directors Qualification}

Irrespective of countries, most of the selected companies discussed the director's qualification in either "Board of Directors" or "Director's profile" segment of the annual report. Bangladeshi companies, Square and ACI disclosed only the "qualification of directors who seek re-appointment". The UK company Hikma disclosed Directors' qualification and experience separately in the annual report. Key topics that have been disclosed by the UK companies regarding "Director's qualification" are skill, experience and other appointment (ACME, GlaxoSmithKline, Orion pharma, AstraZeneca, BTG, Hikma, GlaxoSmithKline, Shire) and qualification of independent directors (Orion). It has been observed the board of directors in the UK are highly qualified (academically and professionally) than that of Bangladeshi director.

\subsubsection{Board Training}

Board training is not obligatory to conform to BSEC Notification, 2012. Therefore, the samples Bangladeshi pharmaceutical companies do not reveal their board training procedure. On the contrary, UK companies i.e. Hikma, Shire and GlaxoSmithKline organize formal induction/training for board members as part of their ongoing assessment of board effectiveness. Board induction is designed to orient and familiarize new directors with the industry and business strategy. A personalized induction is then devised which is designed for each new Director's background, education, experience and role. In the selected UK companies, the Chairman met with each Director individually to discuss his or her ongoing training and development requirements. GlaxoSmithKline, Hikma and Shire conducted board induction and board training for directors and disclosed these in separate sections of the annual report. Key matters that have been discussed in board induction disclosures includegeneral board induction, customized executive and non-executive directors' induction, board business awareness and training (GlaxoSmithKline); induction and development of CFO and non-executive directors (Shire); board training activities (Hikma) and induction of directors, specific training, conference and publication (BTG). The Bangladeshi sample companies did not include anything on the director's training.

\subsubsection{Board Meetings and Attendance}

In Bangladesh, board members have to attend board meetings regularly (as reported by Square and Orion) with few exceptions in GlaxoSmithKline, ACI and ACME. ACME disclosed board meetings and attendance in a separate piece in a separate part of its annual report, while ACI, Square disclosed it in Annexure while Orion and GlaxoSmithKline disclosed it in the Directors report. The disclosures related to board meeting include number 
of board meetings held and meetings attended (ACI, ACME, Square and Orion) and occurrence of the board meeting (GlaxoSmithKline).

Similarly, in the UK, all of the directors have to attend the board meeting regularly (Hikma, BTG and Shire) with few exceptions in GlaxoSmithKline and AstraZeneca. Sampled UK companies disclosed this information as a separate part of their annual report and discussed committee membership and the occurrence of board and committee meeting.

\subsubsection{Board Independence}

Neither of the Bangladeshi pharmaceutical companies included any information regarding board independence. However, selected UK companies (AstraZeneca, BTG, GlaxoSmithKline, Hikma) disclosed the independence of the non-executive directors. Hikma and BTG named this section as "board independence" whereas AstraZeneca, Shire, and GlaxoSmithKline named it as "the independence of non-executive directors". Key disclosures include the name of the independent non-executive directors (AstraZeneca, BTG, GlaxoSmithKline, Hikma), terms of appointment (AstraZeneca, BTG), reasons for appointing independent non-executive directors (AstraZeneca, Hikma) and independence and commitment of non-executive directors (GlaxoSmithKline).

\subsubsection{Role of Independent Directors}

BSEC notifications, 2012 did not report any obligation regarding the role of independent directors. Although Bangladeshi companies disclose the name of independent directors in the "board of directors"; they do not mention anything about their role. Though Square, ACI and Orion wrote a separate paragraph on "Independent directors" in the annual report, they don't mention anything about their role. GlaxoSmithKline and ACME neither include a separate paragraph on independent directors nor disclose anything regarding their role. Selected UK companies clearly disclosed the role of senior independent and non-executive directors in different sections such as "key board role and responsibilities" (GlaxoSmithKline, Hikma), "Board of directors- Division of responsibilities" (BTG, Shire), "key governance roles" (AstraZeneca).

\subsubsection{Role of Board Sub-Committee}

Selected Bangladeshi pharmaceutical companies provided separate sections regarding audit committees in their annual report. The role of audit committee disclosures was included either in audit committee reports (ACI, Square, GlaxoSmithKline, ACME, Orion) or the director's report (GlaxoSmithKlin, ACME) or Annexure (Orion). Square included the role of the audit committee separately and discussed little compared to other Bangladeshi companies. None of the Bangladeshi company disclosed any information about the nomination, remuneration and risk committee; only GlaxoSmithKline discusses a risk committee and executive committee in a separate section. In contrast, selected UK pharmaceutical companies have 4-5 different Board Committees, such as Audit; Nomination and Governance; Remuneration, Compliance, Responsibility and Ethics Committee; Science; and disclosure committee. The roles and responsibilities, highlights and priorities of each committee were clearly depicted in the separate sections. Letters from the chair of each committee had been 
included in each committee report and covered all important aspects dealt with the committee. The role of the nominating Committee had been reported in the "Chairman of the nomination committee's statement" (BTG, GlaxoSmithKline); role of audit committee has been disclosed in "Accountability" (AstraZeneca) and "Chairman of the audit committee's statement" (AstraZeneca, BTG, GlaxoSmithKline), "Audit Committee Responsibilities" (Hikma), "Audit Committee" (Shire) sections. Key points that were disclosed in "board sub-committee" disclosures are discussed in the following:

I. Role of Board Sub-committee (Bangladesh)

\begin{tabular}{|c|c|c|c|c|c|}
\hline $\begin{array}{l}\text { Bangladeshi } \\
\text { Companies }\end{array}$ & ACI & ACME & Glaxo & Orion & Square \\
\hline $\begin{array}{l}\text { Audit } \\
\text { committee }\end{array}$ & $\begin{array}{l}\text { Audit committee } \\
\text { Internal Control } \\
\text { and Business Risk } \\
\text { management } \\
\text { External Auditor, } \\
\text { Summary of } \\
\text { activities of the } \\
\text { Audit Committee }\end{array}$ & $\begin{array}{l}\text { Purpose of Audit } \\
\text { Committee, } \\
\text { Responsibilities of } \\
\text { the Audit Committee } \\
\text { Internal Audit } \\
\text { External Audit } \\
\text { Reporting of the } \\
\text { audit committee } \\
\text { Meeting Attendance } \\
\text { Summary of } \\
\text { Activities during the } \\
\text { Year }\end{array}$ & $\begin{array}{l}\text { Role of the audit } \\
\text { committee, } \\
\text { Activities of the } \\
\text { audit } \\
\text { committee, } \\
\text { Meeting \& } \\
\text { attendance }\end{array}$ & $\begin{array}{l}\text { Membership } \\
\text { Meetings and } \\
\text { Attendance } \\
\text { Functions } \\
\text { Reporting }\end{array}$ & Nil \\
\hline
\end{tabular}

\section{Role of Board Sub-committee (UK)}

\begin{tabular}{|c|c|c|c|c|c|}
\hline UK companies & AstraZeneca & BTG & GlaxoSmithKline & Hikma & Shire \\
\hline $\begin{array}{l}\text { Audit } \\
\text { committee }\end{array}$ & $\begin{array}{l}\text { - Chairman's } \\
\text { Statement } \\
\text { - Activities of audit } \\
\text { committee } \\
\text { - Significant } \\
\text { financial reporting } \\
\text { issues considered } \\
\text { by the Audit } \\
\text { Committee } \\
\text {-Internal Control } \\
\text { - Appointment of } \\
\text { Auditor } \\
\text { - Non-audit service } \\
\text { - Assessing } \\
\text { external audit } \\
\text { effectiveness }\end{array}$ & $\begin{array}{l}\text { Chairman's Statement } \\
\text { Committee } \\
\text { composition } \\
\text { Activities of audit } \\
\text { committee } \\
\text { Financial reporting } \\
\text { Review of external } \\
\text { auditor effectiveness, } \\
\text { independence and } \\
\text { appointment } \\
\text { Risk management and } \\
\text { internal control } \\
\text { Internal audit }\end{array}$ & $\begin{array}{l}\text { Chairman's } \\
\text { Statement } \\
\text { Activities of audit } \\
\text { committee } \\
\text { Significant issues } \\
\text { related to financial } \\
\text { statements } \\
\text { Audit tendering } \\
\text { Appointment of } \\
\text { Auditor } \\
\text { Non-audit service } \\
\text { Fair, balanced and } \\
\text { understandable } \\
\text { assessment } \\
\text { Internal control } \\
\text { framework }\end{array}$ & $\begin{array}{l}\text { Chairman's } \\
\text { Statement } \\
\text { Membership and } \\
\text { attendance } \\
\text { Responsibilities } \\
\text { Significant } \\
\text { accounting } \\
\text { judgements } \\
\text { Fair, balanced and } \\
\text { understandable } \\
\text { assessment } \\
\text { External audit } \\
\text { Risk and associated } \\
\text { disclosures } \\
\text { External auditor } \\
\text { transition }\end{array}$ & $\begin{array}{l}\text { - Membership \& } \\
\text { meeting } \\
\text { - Role of } \\
\text { committees } \\
\text { - Key } \\
\text { consideration } \\
\text {-External audit } \\
\text {-Committee } \\
\text { activities } \\
\text { - Additional } \\
\text { matters }\end{array}$ \\
\hline
\end{tabular}




\begin{tabular}{lll}
\hline $\begin{array}{l}\text { Remuneration } \\
\text { committee }\end{array}$ & $\begin{array}{l}\text { Chairman's } \\
\text { Statement } \\
\text { Annual report for } \\
\text { remuneration } \\
\text { Remuneration } \\
\text { policy }\end{array}$ & $\begin{array}{l}\text { Chairman's Statement } \\
\text { Directors' } \\
\text { Remuneration Policy } \\
\text { Report } \\
\text { Annual report on } \\
\text { remuneration }\end{array}$ \\
& & \\
Nomination & & \\
committee & & Chairman's Statement \\
& & Committee \\
& & membership \\
& & Appointment \\
& & Succession planning \\
& & Committee evaluation
\end{tabular}

Corporate Responsibility Committee

Executive committee

Compliance, Responsibility and Ethics Committee

Science \& technology committee

$\begin{array}{lll}\text { Remuneration } & \text { Chairman's } & \text { Chairman's } \\ \text { policy } & \text { Statement } & \text { Statement } \\ \text { Annual report for } & \text { Membership, } & \text { Annual } \\ \text { remuneration } & \text { attendance } & \text { statement } \\ & \text { Remuneration and } & \text { Annual Report } \\ & \text { performance } & \text { on } \\ \text { summary } & \text { Remuneration } \\ & \text { Directors' } & \text { Directors' } \\ & \begin{array}{l}\text { Remuneration Policy } \\ \text { \& implementation }\end{array} & \text { Remuneration } \\ & \text { Policy } \\ & \text { Annual report for } & \\ \text { remuneration } & \\ \text { Chairman's } & \text { Membership \& } \\ \text { Statement } & \text { Statement } & \text { meeting } \\ & \text { Membership and } & \text { Role of } \\ & \text { attendance } & \text { committees } \\ & \text { Responsibilities } & \text { Key } \\ & \text { Diversity } & \text { consideration } \\ & \text { Succession planning } & \text { Board } \\ & \text { Board review } & \text { appointments } \\ & \text { procedure } \\ & \text { Governance } & \end{array}$

Chairman's

Statement

Responsibilities \& activities of the committee

Directors

Directors profile

Membership \& meeting

Role of committees

Key consideration

Chairman's

Statement

Chairman's

Statement

Responsibilities

Anti-Bribery and Corruption

Responsibility and ethics
Membership \& meeting

Role of committees

Key

consideration 


\subsubsection{Director's Remuneration}

Bangladeshi companies do not comment on "Director's remuneration" as it is not prescribed by BSEC Guideline, 2012. Selected Bangladeshi companies only discussed the aggregate amount paid/provided during the year which did not categorize Directors as executive, non-executive directors, Chairman or CEO etc in "Director's remuneration". There is no classification and separate calculation as salary, bonus, pension, bonus share plan etc in the "Directors Remuneration" disclosures. These are disclosed either in "Directors report" (ACME, Orion, GlaxoSmithKline) "Related parties Transactions" (ACI) or "Notes to the financial statement" (GlaxoSmithKline) and takes very little place. In contrast, Director's remuneration is one of the mandatory requirements of UK Corporate Governance Code, 2014. Selected UK companies have calculated salary, bonus, pension, LTI, bonus share plan, remuneration policy and directors' shareholding etc. in a detailed manner as instructed by the law. Director's remuneration is disclosed either in the "Director's remuneration report" (AstraZeneca, BTG, GlaxoSmithKline, Hikma, Shire) or in "Remuneration committee report" (Hikma).

\subsubsection{Director's Report}

According to BSEC guideline, 2012, all Bangladeshi listed entities should disclose a director's report. Selected Bangladeshi Companies included their Directors' Report in their annual report and follow most of the rules stipulated by the BSEC guideline, 2012. The disclosures related to the Directors' report have been included in appendix. Additionally, the directors' report is not obligatory as per UK Corporate Governance Code, 2014. Some UK companies (AstraZeneca, BTG, GlaxoSmithKline, Hikma) prepared a Directors Report as per UK Companies Act, 2006. Key information discussed in the Director's report is in appendix $\mathrm{v}$ and vi.

III. Directors Report as per BSEC Guideline (Mandatory in Bangladesh)

a) Industry outlook and possible future developments in the industry.

b) Segment-wise or product-wise performance.

c) Risks and concerns.

d) A discussion on Cost of Goods sold, Gross Profit Margin and Net Profit Margin.

e) Discussion on continuity of any Extra-Ordinary gain or loss.

f) Basis for related party transactions

g) Utilization of proceeds from public issues, rights issues and/or through any other instruments.

h) An explanation if the financial results deteriorate after the company goes for Initial Public Offering (IPO), Repeat Public Offering (RPO), Rights Offer, Direct Listing, etc. 
i) If significant variance occurs between Quarterly Financial performance and Annual Financial Statements the management shall explain about the variance in their Annual Report.

j) Remuneration to directors, including independent directors.

k) The financial statements prepared by the management of the issuer company present fairly its state of affairs, the result of its operations, cash flows and changes in equity.

1) Proper books of account of the issuer company have been maintained.

m) Appropriate accounting policies have been consistently applied in preparation of the financial statements and that the accounting estimates are based on reasonable and prudent judgment.

n) International Accounting Standards (IAS)/Bangladesh Accounting Standards (BAS)/International Financial Reporting Standards (IFRS)/Bangladesh Financial Reporting Standards (BFRS), as applicable in Bangladesh, have been followed in preparation of the financial statements and any departure there-from has been adequately disclosed.

o) The system of internal control is sound in design and has been effectively implemented and monitored.

p) There are no significant doubts upon the issuer's company's ability to continue as a going concern. If the issuing company is not considered to be a going concern, the fact along with reasons thereof should be disclosed.

q) Significant deviations from the last year's operating results of the issuer company shall be highlighted and the reasons thereof should be explained.

r) Key operating and financial data of at least preceding 5 (five) years shall be summarized.

s) If the issuer company has not declared a dividend (cash or stock) for the year, the reasons thereof shall be given.

t) The number of Board meetings held during the year and attendance by each director shall be disclosed.

The pattern of shareholding shall be reported to disclose the aggregate number of shares (along with name wise details where stated below) held by:- a) Parent/Subsidiary/Associated Companies and other related parties (name wise details); b) Directors, Chief Executive Officer, Company Secretary, Chief Financial Officer, Head of Internal Audit and their spouses and minor children (name wise details); c) Executives; d) Shareholders holding ten percent (10\%) or more voting interest in the company (name wise details). 
u) In case of the appointment/re-appointment of a director the company shall disclose the following information to the shareholders:- a) a brief resume of the director; b) nature of his/her expertise in specific functional areas; c) names of companies in which the person also holds the directorship and the membership of committees of the board.

IV. Directors' Report Disclosure (Voluntary in the UK)

\begin{tabular}{|c|c|c|c|}
\hline AstraZeneca & BTG & GlaxoSmithKline & Hikma \\
\hline Chief Executive & $\bullet$ Principal Activity & Interest capitalised & Financial- Principal \\
\hline Officer's Review & -Strategic Report & Publication of unaudited financial & activity, Results \\
\hline Therapy Area & $\bullet$ Results and dividends & information & Dividend \\
\hline Review Business & $\bullet$ Directors, their powers \& & Details of any long-term & Creditor payment policy \\
\hline Review & interests & incentive schemes & Donation \\
\hline Resources Review & - Corporate governance & Waiver of emoluments by a & Research \& Development \\
\hline including Employees & -Environmental matters & Director & Interest \\
\hline Financial Review: & -Share capital and & Waiver of future emoluments by & Significant contracts \\
\hline Financial risk & shareholders & a Director Non pre-emptive & Directors- Auditors \\
\hline management & - Change of control & issues of equity for cash & Indemnities, Employment \\
\hline Corporate & -Viability Statement & Non pre-emptive issues of equity & Equity- Capital structure \\
\hline Governance: & -Research \& Development & for cash by any unlisted major & Share issuance, buy-back \\
\hline including the Audit & -Political donations & subsidiary undertaking & Annual General Meeting \\
\hline Committee Report & -Annual General Meeting & Parent company participation in a & Share Substantial \\
\hline and Corporate & - Articles of association & placing by a listed subsidiary & shareholdings \\
\hline Governance Report & •Treasury management & Provision of services by a & Pre-emptive issue of shares \\
\hline Directors' & $\bullet$ Going concern & controlling shareholder & Directors' responsibility \\
\hline Responsibility & -Disclosure of information & Shareholder waiver of & statement \\
\hline Statement & to the auditor & dividends/future dividends & \\
\hline Development & - Auditor & Agreements with controlling & \\
\hline Pipeline & & shareholders & \\
\hline \multicolumn{4}{|l|}{ Sustainability: } \\
\hline \multicolumn{4}{|l|}{ supplementary } \\
\hline \multicolumn{4}{|l|}{ information } \\
\hline \multicolumn{4}{|l|}{ Shareholder } \\
\hline \multicolumn{4}{|l|}{ Information } \\
\hline \multicolumn{4}{|l|}{ Corporate } \\
\hline Information & & & \\
\hline
\end{tabular}




\section{Macrothink}

\subsection{Grey Areas}

UK Corporate Governance Code, 2014 has 19 provisions regarding board disclosures in the annual reports whereas BSEC Notification, 2012 has 10 provisions. BSEC Notification, 2012 focuses on a few aspects regarding the board of directors and Bangladeshi pharmaceutical companies follow these. On average Bangladeshi pharmaceutical companies made eight voluntary disclosures. ACI disclosed the highest number of voluntary information (11), whereas ACME disclosed only four bits of information. On the other hand, UK companies disclose more voluntary board disclosures in the annual reports than that of Bangladeshi companies. AstraZeneca discloses the highest number (16) of voluntary information and GlaxoSmithKline discloses the lowest (6).

\section{Voluntary Disclosures (UK)}

\begin{tabular}{|c|c|c|c|c|}
\hline GlaxoSmithKline & AstraZeneca & Hikma & Shire & BTG (FTSE 250) \\
\hline \multicolumn{5}{|l|}{ Board program } \\
\hline \multicolumn{5}{|l|}{$\begin{array}{l}\text { Board, business } \\
\text { awareness and } \\
\text { training }\end{array}$} \\
\hline \multirow[t]{4}{*}{ Science Committee } & Science Committee & & Science Committee & \\
\hline & $\begin{array}{l}\text { Disclosure } \\
\text { Committee }\end{array}$ & & & $\begin{array}{l}\text { Disclosure } \\
\text { committee }\end{array}$ \\
\hline & & $\begin{array}{l}\text { Compliance } \\
\text { committee }\end{array}$ & & \\
\hline & & & Executive committee & \\
\hline $\begin{array}{l}\text { Committee } \\
\text { evaluation }\end{array}$ & & & & $\begin{array}{l}\text { Committee } \\
\text { evaluation }\end{array}$ \\
\hline \multirow{3}{*}{$\begin{array}{l}\text { Director's } \\
\text { Remuneration } \\
\text { Report }\end{array}$} & Director's & Director's & Director's & Director's \\
\hline & Remuneration Report & Remuneration Report & Remuneration Report & $\begin{array}{l}\text { Remuneration } \\
\text { Report }\end{array}$ \\
\hline & & $\begin{array}{l}\text { Director's report to } \\
\text { shareholder }\end{array}$ & & \\
\hline \multirow[t]{7}{*}{$\begin{array}{l}\text { Audit committee } \\
\text { report }\end{array}$} & $\begin{array}{l}\text { Audit committee } \\
\text { report }\end{array}$ & Audit report & Audit report & Audit report \\
\hline & Board effectiveness & Board effectiveness & Board effectiveness & Board effectiveness \\
\hline & & Board independence & & $\begin{array}{l}\text { Board } \\
\text { independence }\end{array}$ \\
\hline & $\begin{array}{l}\text { Independence of } \\
\text { non-executive } \\
\text { directors }\end{array}$ & & & \\
\hline & Conflict of interest & & Conflict of interest & Conflict of interest \\
\hline & & $\begin{array}{l}\text { Board initiatives \& } \\
\text { priorities }\end{array}$ & $\begin{array}{l}\text { Key activities of the } \\
\text { board }\end{array}$ & \\
\hline & Code of Conduct & & & Corporate policies, \\
\hline
\end{tabular}


values and

compliance

Matters reserved to

the Board

Indemnities and insurance

Ongoing viability

Additional statutory

information on

director, share,

dividend, branch,

earnings, shareholding,

agreements,
Key matters

reserved for the

board

Director's report on

Additional statutory information

Statement of

Director's

responsibility
Disclosure of

information to

auditors

Global Compliance and Internal Audit

(IA)

Subsidiaries and principal activities

Branches \& countries where

Group conducts business

Distributions to shareholders

Dividends
The Board's time spent by area of focus Items for regular discussing at board meetings.

Governance principles 
VI. Voluntary Disclosures (Bangladesh)

\begin{tabular}{l} 
Square \\
\hline Role \& \\
Responsibilities \\
Board Meetings \\
Relationship with \\
Shareholders \& \\
Public \\
\\
\\
Relationship with \\
Government: \\
Relationship with \\
Financers/Bankers \\
Relationship with \\
Suppliers \\
Corporate Social \\
Responsibilities \\
(CSR)
\end{tabular}

Functioning of the

Board

Management through

People

Empowerment of

People

Reporting \&

Communication

$\begin{array}{ll}\text { ACI } & \text { Orion } \\ \begin{array}{l}\text { Roles and } \\ \text { Responsibilities } \\ \text { Board Meetings }\end{array} & \begin{array}{l}\text { Responsibilities of } \\ \text { the Board } \\ \text { Board Meeting }\end{array} \\ \begin{array}{l}\text { Communication with } \\ \text { Shareowners }\end{array} & \begin{array}{l}\text { Communication with } \\ \text { Stakeholders } \\ \text { Investor Relation }\end{array} \\ \begin{array}{l}\text { Management through } \\ \text { People } \\ \text { Empowerment of } \\ \text { People } \\ \text { Reporting \& } \\ \text { Communication }\end{array} & \end{array}$

ACME

GlaxoSmithKline

Role of the Board Role of the Board Role of MD

Board Meetings

Board Meetings \& attendance

Stakeholders

Investor Relation

Executive

Management

Management team

Management

Committee
Executive Committee

Management \& conduct

Other Governance Apparatus Legal Advisers, bankers, insurers,

Auditor's report

Auditor's report
Internal Control and
Risk Management
Business \& Financial
operations review
Directors Re-election

Auditor's report

Risk Management \& Internal Control

Rotation of Directors

Subsidiary Boards
Auditor's report

Auditor's report

Risk Management \& Internal Control

Appointment \& re-appointment of directors

One country executive board

Remuneration 


\section{Macrothink}

Journal of Corporate Governance Research

ISSN 1948-4658

2019, Vol. 3, No. 1

Though some of the Bangladeshi companies do not disclose all corporate governance provision in detailed manner in the annual report, they attach a corporate governance compliance certificate with their annual report, where it is mentioned that all corporate governance provisions have been fulfilled the prescribed manner and certified by a practicing professional accountant. The current research findings supported those by Rahman (1999) that though Bangladeshi companies are reporting more mandatory information than voluntary information, none of the companies are disclosing all mandatory information in their annual reports. In contrast, the UK pharmaceutical companies disclosed most of the provisions in a detailed manner as prescribed by UK Corporate Governance Code.

VII. Compliance with BSEC Corporate Governance Guidelines (Mandatory disclosures)

\begin{tabular}{|c|c|c|c|c|c|c|}
\hline & Title & ACI & ACME & Glaxo & Orion & Square \\
\hline 1.1 & $\begin{array}{l}\text { Board's Size: The number of the board } \\
\text { members shall not be less than } 5 \text { and more } \\
\text { than } 20\end{array}$ & $\checkmark$ & $\checkmark$ & $\checkmark$ & $\checkmark$ & $\checkmark$ \\
\hline 1.2 & Independent Directors: & & & & & \\
\hline $1.2(\mathrm{i})$ & One fifth $(1 / 5)$ of the total number of directors & $\checkmark$ & $\checkmark$ & $\checkmark$ & $\checkmark$ & $\checkmark$ \\
\hline 1.2 (ii) a) & $\begin{array}{l}\text { Does not hold any share or holds less than } 1 \% \\
\text { shares of the total paid-up shares. }\end{array}$ & & & & & \\
\hline 1.2 (ii) b) & $\begin{array}{l}\text { Not connected with any } \\
\text { sponsor/director/shareholder who holds } 1 \% \\
\text { or more shares of the total paid-up shares on } \\
\text { the basis of family relationship. }\end{array}$ & & & & & \\
\hline 1.2 (ii) c) & $\begin{array}{l}\text { Does not have any other relationship, whether } \\
\text { pecuniary or otherwise, with the company or } \\
\text { its subsidiary/associated companies }\end{array}$ & & & & $\checkmark$ & \\
\hline 1.2 (ii) d) & $\begin{array}{l}\text { Not a member, director or officer of any stock } \\
\text { exchange }\end{array}$ & & & & & \\
\hline 1.2 (ii) e) & $\begin{array}{l}\text { Not a shareholder, director or officer of any } \\
\text { member of stock exchange or an intermediary } \\
\text { of the capital market }\end{array}$ & & & & & \\
\hline 1.2 (ii) f ) & $\begin{array}{l}\text { Not a partner or an executive or was not a } \\
\text { partner or an executive during the preceding } 3 \\
\text { (three) years of any statutory audit firm. }\end{array}$ & & & & & \\
\hline 1.2 (ii) g) & $\begin{array}{l}\text { Not be an independent director in more than } 3 \\
\text { (three) listed companies; }\end{array}$ & & & & $\checkmark$ & \\
\hline 1.2 (ii) h) & $\begin{array}{l}\text { Not been convicted by a court of competent } \\
\text { jurisdiction as a defaulter in payment of any } \\
\text { loan to a bank or a NBFI }\end{array}$ & & & & & \\
\hline 1.2 (ii) i) & $\begin{array}{l}\text { Not been convicted for a criminal oVence } \\
\text { involving moral turpitude }\end{array}$ & & & & & \\
\hline 1.2 (iii) & $\begin{array}{l}\text { Nominated by the board of directors and } \\
\text { approved by the shareholders in the AGM }\end{array}$ & & & & & \\
\hline 1.2 (iv) & $\begin{array}{l}\text { Not remain vacant for more than } 90 \text { (ninety) } \\
\text { days. }\end{array}$ & & & & & \\
\hline $1.2(\mathrm{v})$ & Board shall lay down a code of conduct of all & & & & & \\
\hline
\end{tabular}




\section{Macrothink

Board members and annual compliance of the code to be recorded.

1.2 (vi) Tenure of oflce of an independent director shall be for a period of 3 (three) years, which may be extended for 1 (one) term only.

1.3

Qualification of Independent Director (ID)

1.3 (i) Knowledge of Independent Directors

1.3 (ii) Background of Independent Directors

1.3 (iii) $\quad$ Special cases for qualifications

1.5 (i) Industry outlook and possible future developments in the industry

1.5 (ii) Segment-wise or product-wise performance

1.5 (iii) Risks and concerns

1.5 (iv) Discussion on Cost of Goods sold, Gross Profit Margin and Net Profit Margin.

1.5 (v) Discussion on continuity of any Extra-Ordinary gain or loss

1.5 (vi) Basis for related party transactions

1.5 (vii) Utilization of proceeds from public issues, rights issues and/or through any others

1.5 (viii) Explanation if the financial results deteriorate after the company goes for IPO, RPO, Rights OVer, Direct Listing.

1.5 (ix) Explanation about significant variance occurs between Quarterly Financial performance and Annual Financial Statements

$1.5(\mathrm{x}) \quad$ Remuneration to directors including independent directors

1.5 (xi) Fairness of Financial Statement

1.5 (xii) Maintenance of proper books of accounts

1.5 (xiii) Adoption of appropriate accounting policies and estimates

1.5 (xiv) Followed IAS, BAS, IFRS and BFRS in preparation of financial statements

$1.5(\mathrm{xv}) \quad$ Soundness of internal control system

1.5 (xvi) Ability to continue as a going concern

1.5 (xvii) Significant deviations from the last year's operaing results

1.5 (xviii) Key operating and financial data of at least preceding 5 (five) years

1.5 (xix) Reasons for not declared dividend

$1.5(\mathrm{xx}) \quad$ Number of board meetings held during the year and attendance

$1.5(\mathbf{x x i})$

Pattern of shareholding: 
1.5 (xxi) a) Parent/Subsidiary/Associated Companies and 2019, Vol. 3, No. 1 other related parties

1.5 (xxi) b) Directors,CEO,CS,CFO,HIA and their spouses and minor children

$1.5(\mathrm{xxi}) \mathrm{c}) \quad$ Executives

$1.5(\mathrm{xxi}) \mathrm{d}) \quad 10 \%$ or more voting interest

\section{5 (xxii) Appointment/re-appointment of director:}

1.5 (xxii) a) Resume of the director

1.5 (xxii) Expertise in specific functional areas

b)

1.5 (xxii) c) Holding of directorship and membership of committees of the board other then this company.

Appointment of CFO, HIA and CS:

Attendance of CFO and CS at the meeting of the Board of Directors.

\section{3}

\section{Audit Committee :}

Constitution of Audit Committee

Assistance of the Audit Committee to Board of Directors

Responsibility of the Audit Committee

\section{Constitution of the Audit Committee:}

At least 3 (three) members

Appointment of members of the Audit Committee

Qualification of Audit Committee members

Term of Service of Audit Committee members Secretary of the Audit Committee

Quorum of the Audit Committee

\section{Chairman of the Audit Committee}

Board of Directors shall select the Chairman

Chairman of the audit committee shall remain present in the AGM.

\section{Role of Audit Committee}

Oversee the financial reporting process

Monitor choice of accounting policies and principles

Monitor Internal Control Risk management process

Oversee hiring and performance of external auditors

Review the annual financial statements before submission to the board for approval

Review the quarterly and half yearly financial statements before submission to the board for approval

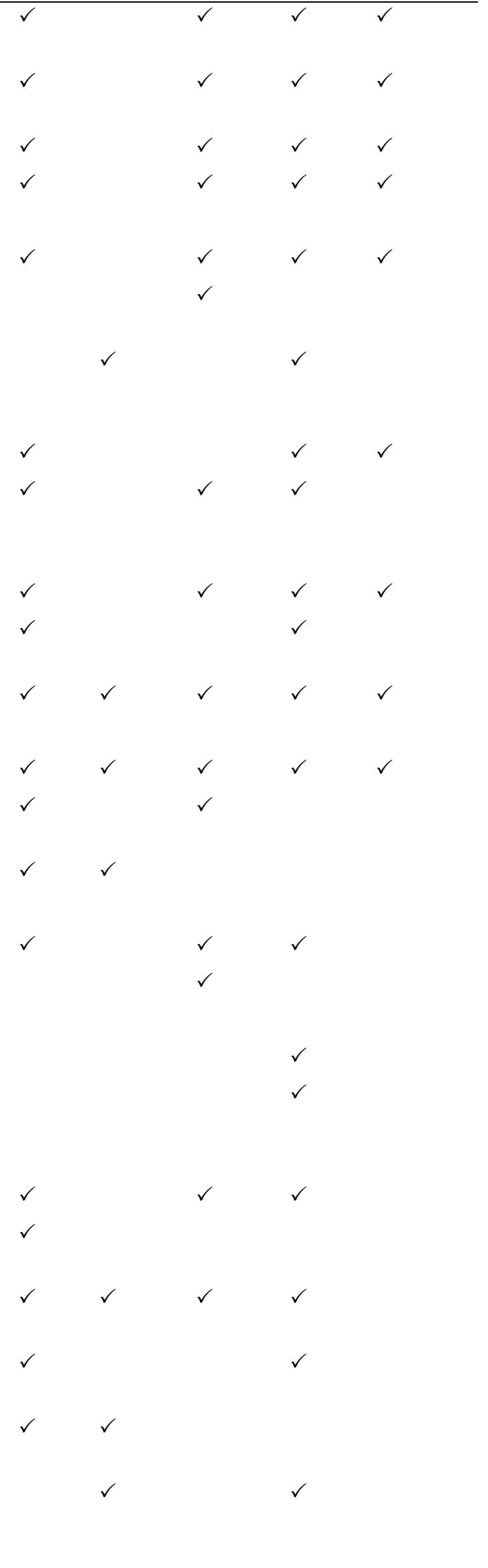




\begin{tabular}{|c|c|c|c|c|c|c|}
\hline 6 (ii) & $\begin{array}{l}\text { Reviewed about fraudulent, illegal or violation } \\
\text { of the company's code of conduct }\end{array}$ & $\checkmark$ & $\checkmark$ & $\checkmark$ & & $\checkmark$ \\
\hline 7 & $\begin{array}{l}\text { Reporting and compliance of corporate } \\
\text { governance }\end{array}$ & & & & & \\
\hline 7 (i) & $\begin{array}{l}\text { Obtain certificate about compliance of } \\
\text { conditions of Corporate Governance } \\
\text { Guidelines }\end{array}$ & $\checkmark$ & $\checkmark$ & $\checkmark$ & $\checkmark$ & $\checkmark$ \\
\hline 7 (ii) & Annexure attached in the directors' report & $\checkmark$ & $\checkmark$ & $\checkmark$ & $\checkmark$ & $\checkmark$ \\
\hline
\end{tabular}

VIII. Compliance with UK Corporate Governance Code (2014) (Mandatory Disclosures)

\begin{tabular}{|c|c|c|c|c|c|}
\hline & GlaxoSmithKline & AstraZeneca & Hikma & Shire & BTG \\
\hline \multicolumn{6}{|l|}{ Leadership } \\
\hline a. The Role of the Board & $\checkmark$ & $\checkmark$ & $\checkmark$ & $\checkmark$ & $\checkmark$ \\
\hline $\begin{array}{l}\text { b. Division of Responsibilities of Chairman } \\
\text { \& Non-Executive Directors }\end{array}$ & $\checkmark$ & $\checkmark$ & $\checkmark$ & $\checkmark$ & $\checkmark$ \\
\hline
\end{tabular}

Effectiveness

a. Board composition (Skills, experience, diversity of the directors)

b. Appointment of directors to the board

c. Commitment (allocate sufficient timeto the board)

d. Development (Board induction)

e. Information \& support (The board should be supplied timely and quality information)

f. Annual performance evaluation of board, committee and directors

g. Re-election of directors

Accountability

a. Financial and Business Reporting (Fair assessment of the company's position and prospects)

b. Risk management and internal control systems.

c. Audit Committee \& Auditors

Remuneration

a. Executive directors' remuneration

Relations with shareholders

a. Dialogue with Shareholders

b. AGM to communicate with investors

Specific requirements for disclosure

a. How the board operates

b. The names of the chairman, the deputy chairman, CEO, Executive, independent director and the chairmen and members of 
the board committees

c. Board meeting and attendance

d. If a CEO is appointed chairman, the reasons for their appointment

e. Details of Nomination committee

f. A statement of how performance evaluation of the board, its committees and its directors has been conducted

g. Director's explanation for preparing the annual reports, accounts and statements

h. Director's explanation for business model \& strategy

i. Director's statement for adopting going concern

j. Assessment of the principal risks by the directors

k. Director's statement for assessing company's current position and principal risks.

1. Board's review of the company's risk management and internal controls systems

m. A separate section describing the functions of audit committee

n. A description of the work of the remuneration committee

o. Explaining the role and the authority delegated to nomination, audit and remuneration committees by the board

p. The terms and conditions of appointment of non-executive directors

q. re-election of a non-executive director

r. appointment or reappointment of an external auditor

s. if the board does not accept the audit committee's recommendation, a statement from the audit committee explaining the recommendation and from the board setting out reasons why they have taken a different position 
company discloses anything about other committees such as nomination committees, remuneration committees, board training, board independence, or role of independent directors and they disclose hardly a little information on directors' remuneration. One of the possible reasons is BSEC Notifications, 2012 does not make it obligatory to disclose these issues which make Bangladeshi companies reluctant to disclose these in the annual report. To do this, a statement of the director's duties (codified in the UK Company Act, 2006) (Section 171-179) can be incorporated in the BSEC Notification, 2012.

IX. Statement of the Directors' Responsibilities (UK Company Act, 2006- Section 171- 179)

A director of a company must act according to the company's constitution, and conduct the duties responsibly (Section 171). A director must work for the benefit of the company and its members (172), employ independent judgment (173), reasonable care, skill and diligence to carry out responsibilities (174), avoid conflict of interest in case of a transaction or arrangement with the company (175). As a director, he must not accept a benefit from a third party (176), must declare his interest in any financial and operational deal (177). The consequences of breach of the sections are the same as the common law rule would apply (178) (adapted from UK Company Act, 2006)

\section{Conclusion and Policy Implication}

This study aimed to comparatively analyze some of the board disclosures in the annual reports of selected pharmaceutical companies between Bangladesh and the UK. The research outcome exposes that the corporate governance regulations in the UK are more stringent and focuses on extensive numbers of board attributes than that in Bangladesh. Though the selected companies disclose mandatory board disclosures in the annual report, significant variations exist in voluntary board disclosure: - the UK companies disclose much more voluntary board disclosures than that of Bangladeshi companies. Sampled Bangladeshi companies attached a corporate governance compliance certificate even though none of the companies describe $100 \%$ mandatory board related information in their annual report. In addition, family dominance is highly prevalent in Bangladeshi board. The UK board of directors is highly qualified (academically and professionally) than that of Bangladeshi director. To improve transparency in board related corporate disclosures BSEC Notifications, 2012 requires some amendment regarding board composition, board training, board independence, the role of independent directors, role of board sub-committees and director's remuneration in the annual report. Some amendment is required in BSEC Notifications, 2012 to ensure transparency in board related corporate disclosures. If these suggestions are adopted, it is expected that these provisions could upgrade the transparency of board disclosure practices in Bangladesh. Future research should incorporate the comparison of the multitude of voluntary disclosure in developing and developed countries. 


\section{MInstitute ${ }_{\text {Mnk }}^{\text {Macrothin }}$}

\section{Data Availability}

Detail information about where the board annual reports can be found

Advanced Chemical Industries Limited (2016). Annual report 2015- 2016, Dhaka: ACI Limited. $\quad$ Retrieved $\quad$ March, $\quad 14, \quad 2017$ from https://www.aci-bd.com/finance/aci/annual/ACIAnnualReport2015-2016.pdf

AstraZeneca (2016). Annual report and form 20-F information 2016. Retrieved March, 17, 2017 from https://www.astrazeneca.com/content/dam/az/Investor_Relations/Annual-report-2016/AZ_A R2016_Full_Report.pdf

BTG plc. (2016). Annual Report and Accounts of BTG plc, 2016. Retrieved March 17, 2017 from https://www.btgplc.com/media/1848/btg_annual_report_2016.pdf

GlaxoSmithKline. (2016). Annual report 2016. Retrieved March, 15, 2017 from http://annualreport.gsk.com/assets/downloads/1_GSK.AR.FULL.V3.pdf

GlaxoSmithKline Bangladesh Limited. (2016). Annual report 2016. Retrieved March, 15, 2017 from http://www.gsk.com/media/3592/bangladesh-annual-report-2015.pdf

HIKMA Pharmaceuticals PLC. (2015). Annual Report of HIKMA Pharmaceuticals PLC 2015. Retrieved March, 17, 2017 from http://www.hikma.com/en/investors.html

Orion Pharma Ltd. (2016). Integrated Annual report 2016. Retreived March 14, 2017 from http://www.orionpharmabd.com/public/financial_report/Annual\%20Report\%202016\%20Part $\% 2001 . p d f$

Shire (2015). Annual report 2015. Retrieved March, 17, 2017 http://investors.shire.com/annual-and-interim-reports/year-2016.aspx

Square Pharmaceuticals Company, (2016). Annual report 2015- 2016. Retrieved March, 13, 2017 http://www.squarepharma.com.bd/spl_15_16.pdf

The ACME Laboratories Ltd, (2016). Annual report 2015- 2016. Retrieved March, 14, 2017 http://acmeglobal.com/acme/wp-content/themes/acme/uploads/Annual_Report_2016.pdf

Detail information about where the BSEC Corporate Governance Notification, 2012 and the UK Corporate Governance Code, 2014 can be found

Bangladesh Security Exchange Commission (BSEC) Corporate Governance Notification. (2012). $\quad$ Retrieved $\quad$ March, $\quad 12, \quad 2017$ from http://www.secbd.org/Notification\%20on\%20CG-07.8.12-Amended.pdf

UK Corporate Governance Code, (2014). Retrieved March, 10, 2017 https://www.frc.org.uk/Our-Work/Publications/Corporate-Governance/UK-Corporate-Gover nance-Code-2014.pdf

Competing interests: No competing interests were disclosed 
Grant Information: The authors declare that no grants were involved in supporting this work.

\section{Acknowledgement}

This article was presented at the International Conference on Accounting Studies, Putrajaya, Malaysia.

\section{References}

Abdelsalam, O. H., \& Street, D. L. (2007). Corporate governance and the timeliness of corporate internet reporting by UK listed companies. Journal of International Accounting, Auditing and Taxation, 16(2), 111-130. https://doi.org/10.1016/j.intaccaudtax.2007.06.001

ABPI. (2017). Industry information. Retrieved March, 31, 2017 from http://www.abpi.org.uk/industry-info/Pages/default.aspx

Adams, R. B., Almeida, H., \& Ferreira, D. (2005). Powerful CEOs and their impact on corporate performance. The Review of Financial Studies, 18(4), 1403-1432. https://doi.org/10.1093/rfs/hhi030

Adams, R. B., Hermalin, B. E., \& Weisbach, M. S. (2008). The role of boards of directors in corporate governance: A conceptual framework and survey. Journal of Economic Literature, 48(1), 58-107. https://doi.org/10.3386/w14486

Akhtaruddin, M. (2005). Corporate mandatory disclosure practices in Bangladesh. The International Journal of Accounting, 40(4), 399-422. https://doi.org/10.1016/j.intacc.2005.09.007

Akhtaruddin, M., Hossain, M. A., Hossain, M., \& Yao, L. (2009). Corporate governance and voluntary disclosure in corporate annual reports of Malaysian listed firms. Journal of Applied Management Accounting Research, 7(1), 1.

Alanezi, F. S., \& Albuloushi, S. S. (2011). Does the existence of voluntary audit committees really affect IFRS-required disclosure? The Kuwaiti evidence. International Journal of Disclosure and Governance, 8(2), 148-173. https://doi.org/10.1057/jdg.2010.33

Alfraih, M. M. (2016). The effectiveness of board of directors' characteristics in mandatory disclosure compliance. Journal of Financial Regulation and Compliance, 24(2), 154-176. https://doi.org/10.1108/JFRC-07-2015-0035

Al-Janadi, Y., Rahman, R. A., \& Omar, N. H. (2013). Corporate governance mechanisms and voluntary disclosure in Saudi Arabia. Corporate Governance, 4(4), 25-35. https://doi.org/10.1057/jdg.2011.19 
Al-Najjar, B., \& Abed, S. (2014). The association between disclosure of forward-looking information and corporate governance mechanisms: Evidence from the UK before the financial crisis period. Managerial Auditing Journal, 29(7), 578-595. https://doi.org/10.1108/MAJ-01-2014-0986

Al-Shammari, B. (2008). Voluntary disclosure in Kuwait corporate annual reports. Review of Business Research, 1(1), 10-30. https://doi.org/10.1057/jdg.2010.3

Alves, H. R. A. M., Rodrigues, A. M., \& Canadas, N. (2012). Factors influencing the different categories of voluntary disclosure in annual reports: An analysis for Iberian Peninsula listed companies. Tekhne, 10(1), 15-26. https://doi.org/10.1016/S1645-9911(12)70003-8

Arcay, M. R. B., \& Vazquez, M. F. M. (2005). Corporate characteristics, governance rules and the extent of voluntary disclosure in Spain. Advances in Accounting, 21, 299-331. https://doi.org/10.1016/S0882-6110(05)21013-1

Arcot, S., Bruno, V., \& Faure-Grimaud, A. (2010). Corporate governance in the UK: Is the comply or explain approach working? International Review of Law and Economics, 30(2), 193-201. https://doi.org/10.1016/j.irle.2010.03.002

Bangladesh Bureau of Statistices. (May 2016). National accounts Statistics. Retrieved September, $\quad 06, \quad 2017 \quad$ from http://bbs.portal.gov.bd/sites/default/files/files/bbs.portal.gov.bd/page/cdaa3ae6_cb65_4 066_8c61_d97e22cb836c/National_Accounts_Blue_Book_2016.pdf

Barako, D. G., Hancock, P., \& Izan, H. Y. (2006). Factors influencing voluntary corporate disclosure by Kenyan companies. Corporate Governance: an international review, 14(2), 107-125. https://doi.org/10.1111/j.1467-8683.2006.00491

Bhuiyan, M., Ullah, H., \& Biswas, P. K. (2007). Corporate governance and reporting: An empirical study of the listed companies in Bangladesh. Dhaka University Journal of Business Studies, 28(1).

Biswas, P. K. (2012). Corporate governance guidelines in Bangladesh: Some observations. The Cost and Management, 11(4).

Chandra, N. (2002). Chandra Report on Corporate Governance. Retrieved May, 06, 2017 from http://www.nfcgindia.org/executive_summary.htm

Chau, G. K., \& Gray, S. J. (2002). Ownership structure and corporate voluntary disclosure in Hong Kong and Singapore. The International journal of accounting, 37(2), 247-265. https://doi.org/10.1016/S0020-7063(02)00153-X

Cheffins, B. R. (1997). Company law: theory, structure, and operation. Oxford: Clarendon Press.

Chen, C. J., \& Jaggi, B. (2000). Association between independent non-executive directors, family control and financial disclosures in Hong Kong. Journal of Accounting and 
Public policy, 19(4-5), 285-310. https://doi.org/10.1016/S0278-4254(00)00015-6

Cheung, Y. L., Jiang, P., \& Tan, W. (2010). A transparency disclosure index measuring disclosures: Chinese listed companies. Journal of Accounting and Public Policy, 29(3), 259-280. https://doi.org/10.1016/j.jaccpubpol.2010.02.001

Chithambo, L., \& Tauringana, V. (2017). Corporate governance and greenhouse gas disclosure: A mixed-methods approach. Corporate Governance: The International Journal of Business in Society, 01-43. https://doi.org/10.1108/CG-10-2016-0202

Companies Act, 2006 (c.46), Part 10, Chapter 2. Retrieved April, 25, 2017 from http://www.legislation.gov.uk/ukpga/2006/46/part/10/chapter/2

Crombie, N. A. (2013). Institutional logics of corporate governance and the discourse on executive remuneration. $\mathrm{PhD}$. University of Canterbury. Retrieved from https://ir.canterbury.ac.nz/bitstream/handle/10092/8202/Thesis_Fulltext.pdf?sequence=1

De Andres, P., \& Vallelado, E. (2008). Corporate governance in banking: The role of the board of directors. Journal of banking \& finance, 32(12), 2570-2580. https://doi.org/10.1016/j.jbankfin.2008.05.008

Dedman, E., Lin, S. W. J., Prakash, A. J., \& Chang, C. H. (2008). Voluntary disclosure and its impact on share prices: Evidence from the UK biotechnology sector. Journal of $\begin{array}{llll}\text { Accounting and Public } \quad \text { Policy, } & \text { 27(3), }\end{array}$ https://doi.org/10.1016/j.jaccpubpol.2008.02.001

Dey, S. (2016). Corporate Governance Reporting in Bangladesh: A Study of Selected Listed Private Commercial Banks of Bangladesh. International Journal of Business Ethics in Developing Economies, 5(1).

Dezzani, L. (2017). Top 10 Pharmaceutical Companies, 2017. Retrieved from https://igeahub.com/2017/03/14/top-10-pharmaceutical-companies-2017/

Donaldson, L. (1990). The ethereal hand: Organizational economics and management theory. Academy of management Review, 15(3), 369-381. https://doi.org/10.5465/amr.1990.4308806

Donnelly, R., \& Mulcahy, M. (2008). Board structure, ownership, and voluntary disclosure in Ireland. Corporate Governance: An International Review, 16(5), 416-429. https://doi.org/10.1111/j.1467-8683.2008.00692.x

Elmagrhi, M. H., Ntim, C. G., \& Wang, Y. (2016). Antecedents of Voluntary Corporate Governance Disclosure: A Post2007/08 Financial Crisis Evidence from the Influential UK Combined Code. Corporate Governance, 16(3), 507-538. https://doi.org/10.1108/CG-01-2016-0006

Emergingmarketsesg.net, (December, 2005)。 Three Models of Corporate Governance from Developed Capital Markets. Retrieved April, 13, 2017 from http://www.emergingmarketsesg.net/esg/wp-content/uploads/2011/01/Three-Models-of- 
Corporate-Governance-January-2009.pdf

Eng, L. L., \& Mak, Y. T. (2003). Corporate governance and voluntary disclosure. Journal of $\begin{array}{lll}\text { accounting and public } & \text { 22(4), }\end{array}$ https://doi.org/10.1016/S0278-4254(03)00037-1

Evans, J. H., \& Sridhar, S. S. (1996). Multiple control systems, accrual accounting, and earnings management. Journal of Accounting Research, 34(1), 45-65. https://doi.org/10.2307/2491331

Export Promotion Bureau (EPB), 2016. Retrieved from http://epb.portal.gov.bd/site/files/51916ae6-a9a3-462e-a6bd-9ef074d835af/Statistic-Dat a-2016-2017

Export Promotion Bureau (EPB) (2016). Retrieved September, 06, 2017 from http://epb.portal.gov.bd/site/files/51916ae6-a9a3-462e-a6bd-9ef074d835af/Statistic-Dat a-2016-2017

Ferrarini, G., Moloney, N., \& Ungureanu, M. (2009). Understanding Directors' Pay in Europe: A Comparative and Empirical Analysis, ECGI - Law Working Paper No. 126. https://dx.doi.org/10.2139/ssrn.1418463

German Corporate Governance Code, (2010). Retrieved May, 06, 2016 from www.dcgk.de/en/code/archive.html?file=files/dcgk/usercontent/en/.../code/...2010...

Ghazali, N. A. M., \& Weetman, P. (2006). Perpetuating traditional influences: Voluntary disclosure in Malaysia following the economic crisis. Journal of International Accounting, Auditing and Taxation, 15(2), 226-248. https://doi.org/10.1016/j.intaccaudtax.2006.08.001

Grant Thornton, (2010). Corporate governance in India and the UK compared. Retrieved May, $\quad 06, \quad 2016$ from https://www.grantthornton.co.uk/insights/corporate-governance-in-india-and-the-uk-a-c omparative-analysis/

Gul, F. A., \& Leung, S. (2004). Board leadership, outside directors' expertise and voluntary corporate disclosures. Journal of Accounting and public Policy, 23(5), 351-379. https://doi.org/10.1016/j.jaccpubpol.2004.07.001

Haque, T., Jahan, M. A., \& Khan, M. H. Z. (2007). Corporate disclosures through Director's report- Compliance of the Companies Act, 1994. The Cost and Management, 35(1), 2835.

Hassan, O. A., Romilly, P., Giorgioni, G., \& Power, D. (2009). The value relevance of disclosure: Evidence from the emerging capital market of Egypt. The International Journal of Accounting, 44(1), 79-102. https://doi.org/10.1016/j.intacc.2008.12.005

Hermalin, B. E., \& Weisbach, M. S. (1998). Endogenously chosen boards of directors and their monitoring of the CEO. American Economic Review, 96-118. 
Ho, S. S., \& Wong, K. S. (2001). A study of the relationship between corporate governance structures and the extent of voluntary disclosure. Journal of International Accounting, Auditing and Taxation, 10(2), 139-156. https://doi.org/10.1016/S1061-9518(01)00041-6

Hong Kong Society of Accountants, (HKSA) (2001). Corporate Governance Disclosure in Annual Reports: A guide to current requirements and recommendations for $\begin{array}{lllll}\text { enhancement. } & \text { Retrieved } & \text { March, } & \text { 12, } & \end{array}$ http://www.ecgi.org/codes/documents/hksa.pdf

Hossain, D. M., Salat, A., \& Al-Amin. (2005). Voluntary Disclosure on Corporate Social Responsibility: A Study on the Annual Reports of Bangladeshi Companies. The Bangladesh Accountant, 47(20), 28-34.

Hossain, M. (2008). The extent of disclosure in annual reports of banking companies: The case of India. European Journal of Scientific Research, 23(4), 659-680. https://doi.org/10.1002/csr.154

Hossain, M., \& Hammami, H. (2009). Voluntary disclosure in the annual reports of an emerging country: The case of Qatar. Advances in Accounting, 25(2), 255-265. https://doi.org/10.1016/j.adiac.2009.08.002

International Comparative Legal guides. (ICLG). (19/06/2017). USA Corporate Governance, 2016. Retrieved June $25, \quad 2017$ from https://iclg.com/practice-areas/corporate-governance/corporate-governance-2016/usa

International Monetary Fund (IMF) (April, 2016). World Economic Outlook, April 2016: Too Slow for Too Long. Retrieved September, 06, 2017 from https://www.imf.org/en/Publications/WEO/Issues/2016/12/31/World-Economic-Outlook -April-2016-Too-Slow-for-Too-Long-43653

International Monetary Fund. (April, 2017). World Economic Outlook Database. Retrieved $\begin{array}{llll}\text { March 21, } 2017 & \text { from }\end{array}$ http://www.imf.org/external/pubs/ft/weo/2017/01/weodata/weorept.aspx?

Islam, M. S., Al-Hossienie, C. A., \& Al-Baki, C. A. (2010). Corporate governance and voluntary information disclosure: a study of listed financial companies in Bangladesh. AIUB Journal of Business and Economics, 9(1), 81-96.

Japan's Corporate Governance Code, (2015). Tokyo Stock Exchange, Inc. Retrieved March, 21 , 2017 from http://www.jpx.co.jp/english/equities/listing/cg/tvdivq0000008jdy-att/20150513.pdf

Jensen, M. C., \& Meckling, W. H. (1976). Theory of the firm: Managerial behavior, agency costs and ownership structure. Journal of financial economics, 3(4), 305-360. https://doi.org/10.1016/0304-405X(76)90026-X

Kabir, M. A. (2008). Corporate Governance in Bangladesh. Unpublished doctoral dissertation, University of Chittagong. 
Laux, V. (2008). Board independence and CEO turnover. Journal of Accounting Research, 46(1), 137-171. https://doi.org/10.1111/j.1475-679X.2008.00269.x

Leventis, S., \& Weetman, P. (2004). Voluntary disclosures in an emerging capital market: some evidence from the Athens Stock Exchange. Advances in International Accounting, 17, 227-250. https://doi.org/10.1016/S0897-3660(04)17011-6

Li, J., Pike, R., \& Haniffa, R. (2008). Intellectual capital disclosure and corporate governance structure in UK firms. Accounting and Business Research, 38(2), 137-159. https://doi.org/10.1080/00014788.2008.9663326

Mahoney, P. G. (1995). Mandatory disclosure as a solution to agency problems. The University of Chicago Law Review, 62(3), 1047-1112. https://doi.org/10.2307/1600055

Mallin, C., \& Ow-Yong, K. (2009). Corporate governance in alternative investment market (AIM) companies: determinants of corporate governance disclosure. https://doi.org/10.2139/ssrn.1326627

Mollah, S., \& Zaman, M. (2015). Shari'ah supervision, corporate governance and performance: Conventional vs. Islamic banks. Journal of Banking \& Finance, 58, 418-435. https://doi.org/10.1016/j.jbankfin.2015.04.030

Nicholls, D., \& Ahmed, K. (1995). Disclosure quality in corporate annual reports of non-financial companies in Bangladesh. Research in Accounting in Emerging Economies, 3(2), 149-170.

Nicholson, G. J., \& Kiel, G. C. (2007). Can directors impact performance? A case - based test of three theories of corporate governance. Corporate Governance: An International Review, 15(4), 585-608. https://doi.org/10.1111/j.1467-8683.2007.00590.x

Ntim, C. G. (2015). Board diversity and organizational valuation: unravelling the effects of ethnicity and gender. Journal of Management \& Governance, 19(1), 167-195. https://doi.org/10.1007/s10997-013-9283-4

Ntim, C. G., Soobaroyen, T., \& Broad, M. (2015). Governance structures, voluntary disclosures and public accountability: The case of UK higher education institutions. Accounting, Auditing \& Accountability Journal, 30(1), 65-118. https://doi.org/10.1108/AAAJ-10-2014-1842

Pagano, M., \& Volpin, P. F. (2005). The political economy of corporate governance. The American Economic Review, 1005-1030. https://doi.org/10.1257/0002828054825646

Pfeffer, J., \& Salanick, G. (1978). The external control of organizations: A resource dependence perspectives. New York: Harper \& Row.

Rahman, M. M. (1999). The Extent of Mandatory and Voluntary Financial Disclosure by Listed Companies in Bangladesh: An Empirical Study. Dhaka University Journal of Business Studies, 20(1), 189-208. 
Rashid, A., De Zoysa, A., Lodh, S., \& Rudkin, K. (2010). Board composition and firm performance: Evidence from Bangladesh. Australasian Accounting Business \& Finance Journal, 4(1), 76.

Rouf, D., \& Abdur, M. (2011). Corporate characteristics, governance attributes and the extent of voluntary disclosure in Bangladesh. African Journal of Business Management, 5(19), 7836-7845. https://doi.org/10.5897/AJBM10.1180

$\begin{array}{llllll}\text { Sarbanes-Oxley } \quad \text { Act, } & \text { (2002). } & \text { Retrieved }\end{array}$ https://www.sec.gov/about/laws/soa2002.pdf

Sartawi, I. I. M., Hindawi, R. M., Bsoul, R., \& Ali, A. E. J. (2014). Board composition, firm characteristics, and voluntary disclosure: The case of Jordanian firms listed on the Amman stock exchange. International Business Research, 7(6), 67-82. https://doi.org/10.5539/ibr.v7n6p67

Sharma, N. (2014). Extent of corporate governance disclosure by banks and finance companies listed on Nepal Stock Exchange. Advances in Accounting, 30(2), 425-439. https://doi.org/10.1016/j.adiac.2014.09.014

Sharma, N., Bejou, A., \& Bejou, D. (2012). Performance indicators of compassionate companies. Journal of Relationship Marketing, 11(1), 7-14. https://doi.org/10.1080/15332667.2011.653432

Soni, A. (2015). Impact of Sarbanes Oxley (SOX) Act on Corporate Governance Practices. Pacific Business Review International, 8(6), 38-43.

State of Delaware official website. (2017). About Agency. Retrieved May, 06, 2017 from http://www.corp.delaware.gov/aboutagency.shtml

Statement of director's duties, Companies Act. (2006). Retrieved July, 10, 2017 from http://www.legislation.gov.uk/ukpga/2006/46/contents

Uddin, S., \& Choudhury, J. (2008). Rationality, traditionalism and the state of corporate governance mechanisms: Illustrations from a less-developed country. Accounting, Auditing \& Accountability Journal, 21(7), 1026-1051. https://doi.org/10.1108/09513570810907465

UK trade and investment fact sheet, (2006). Overview: The UK Pharmaceutical and $\begin{array}{lllll}\text { Biotechnology Industry. } & \text { Retrieved } & \text { March, }\end{array}$ http://www.eisai.com/news/epdf200602211.pdf

\section{Copyright Disclaimer}

Copyright for this article is retained by the author(s), with first publication rights granted to the journal.

This is an open-access article distributed under the terms and conditions of the Creative Commons Attribution license (http://creativecommons.org/licenses/by/3.0/). 